\title{
IKK $\beta$ as a target for treatment of inflammation induced bone loss
}

\section{G Ruocco, M Karin}

Ann Rheum Dis 2005;64:iv81-iv85. doi: 10.1136/ard.2005.042721

The transcription factor nuclear factor (NF)- $\kappa B$ is well recognised as a pivotal player in osteoclastogenesis and inflammation induced bone loss. Here, the authors discuss their recent results, obtained using a genetic approach in mice, that indicate the importance of IKK $\beta$, and not IKK $\alpha$, as a transducer of signals from receptor activator of NF- $\kappa B$ (RANK) to NF- $\kappa \mathrm{B}$. Ablation of IKK $\beta$ results in lack of osteoclastogenesis and unresponsiveness of IKK $\beta$ deficient mice to inflammation induced bone loss. In the need of a more effective therapy for the treatment of inflammatory diseases causing bone resorption, specific inhibition of IKK $\beta$ represents a logical alternative strategy to the current therapies.

G enerally, inflammation is a beneficial host response to foreign challenge or tissue injury that leads ultimately to restoration of tissue structure and function. In fact, inflammation is an integral part of innate immunity. However, prolonged inflammation that is not resolved ceases to be beneficial and contributes to the pathogenesis of many disease states. ${ }^{1}$ Excessive bone resorption is a major pathological factor in chronic inflammatory diseases such as periodontitis, osteoporosis, and arthritis, and it is now clear that dysregulation of immune and inflammatory responses is crucial for initiating the bone destruction associated with these conditions. ${ }^{2}$ The bone-resorbing osteoclasts are known to play a pivotal role in focal bone erosion in rheumatoid arthritis (RA) ${ }^{3}$ and in animal models of arthritis. ${ }^{4}$ Study of tissues obtained from the bone-pannus in RA demonstrated the presence of multinucleated osteoclast-like cells, $^{35}$ and in situ hybridisation revealed that these cells expressed mRNA for definitive osteoclast markers such as tartrate resistant acid phosphatase (TRAP), cathepsin K, and calcitonin receptor. In addition, electron microscopic analysis of subchondral bone from damaged RA metacarpals confirmed the presence of resorption areas typical of osteoclast activity. ${ }^{6}$ In normal bone physiology osteoclasts differentiate from their haematopoietic precursors and their differentiation is dramatically dependent on osteoblastic/stromal cells of mesenchymal origin that provide a physical support for nascent osteoclasts and produce several soluble and membrane associated factors that stimulate the proliferation and/ or differentiation of haematopoietic osteoclast precursors. ${ }^{7}$ Imbalances between osteoclast and osteoblast activities can arise from a variety of hormonal changes or perturbations of inflammatory and growth factors, resulting in skeletal abnormalities characterised by decreased (osteoporosis) or increased (osteopetrosis) bone mass, ${ }^{7-9}$ and the focal net loss of bone in sites of inflammation, as found in RA. ${ }^{3}$ In animal models in which expression of key proinflammatory mediators has either been abolished through gene knockouts or their activities modulated through genetic and biochemical blockade, the decrease in the inflammatory response is closely associated with reduction in the degree of bone and cartilage destruction. ${ }^{10-13}$ Pettit and colleagues demonstrated that arthritis can be induced in mice lacking osteoclasts (due to the deletion of the key osteoclast differentiation factor, receptor activator of nuclear factor (NF)- $\mathrm{\kappa B}$ ligand (RANKL)), although bone erosion does not occur. ${ }^{14}$ Similar results were obtained in mice lacking the transcription factor c-fos, which is also required for osteoclast maturation. ${ }^{12}$ Despite the development and progression of inflammation, these mice were resistant to focal bone erosion as a result of the absence of osteoclasts. Thus, interference with osteoclast formation or maturation represents an attractive strategy for the treatment and prevention of inflammation induced bone loss, suggesting that blockade of RANKL signalling in combination with an anti-inflammatory cytokine may have effects on both bone erosion and inflammation.

\section{THE RANKL-RANK SYSTEM IN PHYSIOLOGICAL AND PATHOLOGICAL BONE REMODELLING}

Two proteins crucial for osteoclast development and activation are RANK (receptor activator of NF- $\mathrm{KB}$ ) and its ligand, RANKL. RANKL is a member of the tumour necrosis factor (TNF) family of cytokines and its expression is regulated by a number of factors that induce bone resorption including vitamin $\mathrm{D}_{3}$, glucocorticoids, interleukin (IL)-1, IL-6, and TNF $\alpha .{ }^{15-17}$ RANKL activates mature osteoclasts and directs osteoclast differentiation from monocyte/macrophage precursors together with macrophage-colony stimulating factor (M-CSF). ${ }^{17}{ }^{18}$ The in vivo significance of the RANKL-RANK signalling pathway has been verified by the observations that ablation of either protein in mice results in severe osteopetrosis and a total lack of osteoclasts, ${ }^{19} 20$ whereas a deficiency in osteoprotegerin (OPG), which binds to RANK preventing activation of RANK signalling, results in osteoporosis. ${ }^{21} \mathrm{~A}$ crucial target of RANKL signalling is transcription factor NF- $\kappa \mathrm{B}$, a finding that implicates this transcription factor in osteoclast differentiation. A critical role for NF- $\mathrm{KB}$ in osteoclastogenesis is supported by the fact that gene specific deletion of both its p50 and p52 subunits causes severe osteopetrosis through the absence of osteoclasts. ${ }^{22} 23 \mathrm{In}$ osteoclasts, RANK induces the activation of Akt, which is blocked by the phosphatidylinositol 3 kinase (PI3K) inhibitor LY294002. ${ }^{24} 25$ Furthermore, LY294002 reduces the RANK mediated survival response of osteoclasts. ${ }^{25}$ The PI3K inhibitor also displays a potent inhibitory effect on osteoclast differentiation, ${ }^{24}$ which may result from a reduced survival of osteoclast precursors during differentiation. Although direct evidence for RANK activation of PI3K remains to be demonstrated, it has been shown in osteoclasts that RANK

Abbreviations: IKK, IKB kinase; IL, interleukin; LPS, lipopolysaccharide; OPG, osteoprotegerin; RA, rheumatoid arthritis; RANKL, receptor activator of nuclear factor (NF)- $\mathrm{KB}$ ligand; $T N F$, tumour necrosis factor; TNF-R, TNF receptor 
activated the Src tyrosine kinase. The relevance of Src activity to RANK signalling is underscored by the osteopetrotic phenotype of mice deficient in Src. ${ }^{26}$ In Src deficient mice osteoclast motility, and therefore bone resorption, are prevented due to lack of association of Src with gelsolin, ${ }^{27}$ and thereby inhibiting formation of actin filaments and downregulating the level of Pyk2 and c-Cbl. ${ }^{28} 29$

The RANKL-RANK system also represents a direct link between synovial $\mathrm{T}$ cell infiltration and bone erosion in RA. There is mounting evidence that $\mathrm{T}$ lymphocytes regulate osteoclast formation in arthritis. The requirement for RANKL in mediating osteoclast differentiation and function in inflammatory arthritis has been supported by several lines of evidence. ${ }^{3} 121416$ 30-32 Initial observations demonstrated that activated $\mathrm{T}$ cells provide a source of RANKL for subsequent osteoclast differentiation in rat adjuvant induced arthritis. ${ }^{3}$ RANKL production by activated $\mathrm{T}$ cells directly controls osteoclastogenesis and bone remodelling and explains why autoimmune diseases, cancers, leukaemias, asthma, chronic viral infections, and periodontal disease result in systemic and local bone loss. ${ }^{3}$ In particular, RANKL seems to be a principal pathogenetic factor that causes bone and cartilage destruction in arthritis. Inhibition of RANKL function via its natural decoy receptor OPG prevents bone loss in postmenopausal osteoporosis and cancer metastases and completely blocks bone loss and crippling in various rodent models of arthritis. Perhaps, the most important evidence of the crucial role that osteoclasts play in inflammation induced bone loss comes from the study in which OPG was successfully used to block bone erosion in collagen induced arthritis mice. ${ }^{3}$

\section{ROLE OF TNF $\alpha$ IN INFLAMMATION INDUCED BONE LOSS}

Additional cytokines and growth factors that are also produced by cells of the inflamed synovium, primarily the proinflammatory cytokines TNF $\alpha$ and IL-1, can also stimulate osteoclast development, thus providing a potential link between the inflammatory process and bone destruction..$^{33-35}$ Similar to RANKL, TNF $\alpha$ is a potent osteoclastogenic factor that enhances proliferation and differentiation of osteoclast precursors through its type 1 receptor, TNF-R1. ${ }^{35}{ }^{36}$ However, permissive levels of RANKL are required for optimal TNF $\alpha$ induced osteoclastogenesis, most likely due to the inability of $\mathrm{TNF} \alpha$ to support calcium intake. TNF $\alpha$ mediates RANKL stimulation of osteoclast differentiation through an autocrine mechanism. ${ }^{37}$

TNF $\alpha$ exerts its biological functions through two receptors: TNF-R1 (p55) and TNF-R2 (p75). Both receptors are expressed on a wide variety of cell types including bone marrow haematopoietic cells. ${ }^{38}$ Amongst the two receptors it is TNF-Rl that mediates most of the biological effects of $\mathrm{TNF} \alpha$, including programmed cell death and the activation of NF- $\kappa B .{ }^{39}$ Upon oligomerisation, TNF-Rl binds to and recruits TNFR associated death domain protein (TRADD) molecules and binds indirectly to Fas associated death domain protein (FADD) through an interaction between the death domains of FADD and TRADD. This interaction leads to the activation of a caspase cascade responsible for programmed cell death. ${ }^{40}$ In contrast, TNF-R2 lacks a death domain and interacts directly with TRAF (TNF associated factor) 2. Although, TRAF 2 activates both NF- $\kappa \mathrm{B}$ and c-Jun-N-terminal kinase $(\mathrm{JNK}),{ }^{41}$ TNF-R2 make very little contribution to NF- $\kappa \mathrm{B}$

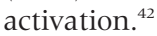

Osteoclast recruitment by TNF $\alpha$ is probably essential to the pathogenesis of inflammatory osteolysis, whereas TNF-Rl promotes osteoclastogenesis, TNF-R2 was shown to inhibit this process. ${ }^{36} \mathrm{TNF} \alpha$ is produced primarily by activated $\mathrm{T}$ cells and activated macrophages within the inflamed synovial tissue in $\mathrm{RA}^{43}{ }^{44}$ The prominent role of TNF $\alpha$ in driving inflammation has made it a target for biologically based therapeutics currently used for treatment of RA. ${ }^{45-49}$ TNF $\alpha$ alone is sufficient to induce arthritis and joint destruction in a murine model. Mice constitutively expressing human TNF $\alpha$ develop polyarthritis, which is characterised by significant focal bone erosion as well as generalised bone loss. ${ }^{11}{ }^{12} 32$ Conversely, mice deficient in TNF $\alpha$ demonstrated a heterogeneous phenotype when challenged with serum transfer arthritis. The absence of TNF $\alpha$ signalling mostly conferred resistance to synovitis and bone erosion, but approximately a third of the animals studied did develop clinical signs of arthritis, albeit at a delayed rate and reduced severity compared with wild-type littermates. ${ }^{10}$ Furthermore, focal bone erosion, correlating roughly with the degree of inflammation, was evident within the affected joints in the animals that did develop clinical arthritis (CIA). ${ }^{10}$ This study supported previous observations in which mice deficient in TNF $\alpha$ were subject to collagen induced arthritis, ${ }^{50}$ suggesting that TNF $\alpha$ independent pathways can compensate for the loss of TNF $\alpha$ signalling in mediating inflammation and subsequent bone erosion. ${ }^{10}{ }^{50} \mathrm{TNF} \alpha$ antagonists, either alone ${ }^{51-54}$ or in combination with the immunosuppressant methotrexate ${ }^{45-}$ 49 55-59 have demonstrated efficacy in reducing signs and symptoms of RA and arresting progression of erosions in a large number of patients with RA. Despite its apparent efficacy, it is not effective in all patients. Some of them, indeed, do not respond to anti-TNF $\alpha$ therapy, and complete disease remission, including the prevention of bone loss, is not always achieved. This suggests that, as in experimental arthritis models, alternative pathways that mediate inflammation and bone erosion may contribute to the heterogeneity of disease, and that in cases in which $\mathrm{TNF} \alpha$ blockade is insufficient to control the disease process, alternative therapeutic strategies need to be considered.

\section{NF- $\kappa$ B AND IKK $\beta$ AS REGULATORS OF INFLAMMATION AND BONE REMODELLING}

$\mathrm{NF}-\kappa \mathrm{B}$ activity is regulated through interaction with specific inhibitors, IкBs, which trap NF- $\kappa \mathrm{B}$ dimers in the cytoplasm. ${ }^{60}$ In response to cell stimulation with proinflammatory and innate immune stimuli, such as TNF $\alpha$, IL-1, or bacterial endotoxin (lipopolysaccharide (LPS)), the IкBs are phosphorylated at two conserved serines and targeted to rapid ubiquitin dependent proteolysis. ${ }^{61}$ I $\kappa \mathrm{B}$ phosphorylation is carried out by the I $\kappa \mathrm{B}$ kinase (IKK), a complex composed of three subunits: IKK $\alpha, \operatorname{IKK} \beta$, and $\operatorname{IKK} \gamma / \mathrm{NF}-\kappa \mathrm{B}$ essential modulator (NEMO). ${ }^{62}$

IKK $\alpha$ and IKK $\beta$ serve as the catalytic subunits, whereas IKK $\gamma /$ NEMO is the regulatory subunit. IKK $\alpha$ and IKK $\beta$ contain similar kinase domains with essentially identical activation loops. ${ }^{63}{ }^{64}$ Despite their structural and biochemical similarities, IKK $\alpha$ and IKK $\beta$ are functionally distinct. ${ }^{62}$ Whereas IKK $\beta$ is essential for NF- $\mathrm{NB}$ activation in response to proinflammatory and innate immune stimuli, IKK $\alpha$ is not required for such responses. ${ }^{65-68}$ IKK $\alpha$, however, plays a unique and critical role in development of the epidermis, ${ }^{65}$ but its ability to induce keratinocyte differentiation is independent of its protein kinase activity or NF- $\kappa \mathrm{B} .{ }^{69}$ Recently, IKK $\alpha$ was found to be required for $B$ cell maturation, another unique function that is not provided by $\operatorname{IKK} \beta .^{70}$ This function is dependent on $\operatorname{IKK} \alpha$ kinase activity, but instead of being mediated through inducible I $\kappa \mathrm{B}$ degradation, is exerted via a second NF- $\kappa \mathrm{B}$ activation pathway, dependent on processing of the NF- $\mathrm{BB} 2 / \mathrm{p} 100$ precursor protein to the mature p52 subunit. ${ }^{70}$ This pathway requires the activity of another protein kinase, NIK (NF- $\kappa \mathrm{B}$ inducing kinase), which may function as an activator of IKK $\alpha .^{70}$ It was observed that NIK deficient osteoclast precursors do not respond to RANKL in an in vitro 


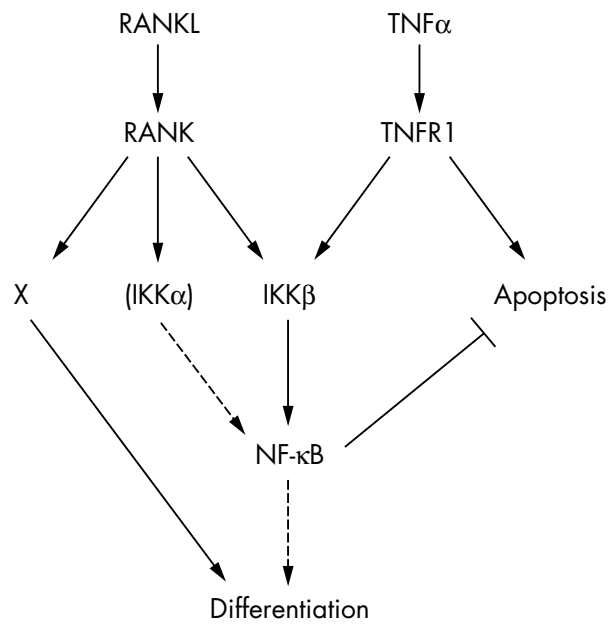

Figure 1 Schematic model of receptor activator of nuclear factor (NF)$\kappa \mathrm{B}$ ligand (RANKL) and tumour necrosis factor $\alpha$ (TNF $\alpha$ ) signalling during osteoclastogenesis and inflammation induced bone loss. $X$, a pathway other than I $\mathrm{\kappa} B$ kinase (IKK)/NF- $\kappa B$ that is activated by RANKL binding to RANK and is essential for production of functional osteoclasts. IKK $\alpha$ function in RANK signalling is dispensable. TNFR1, TNF receptor 1.

differentiation system devoid of osteoblasts. ${ }^{71}$ However, aly mice, which carry a point mutation in the Nik gene that prevents NIK activation, are not osteopetrotic. ${ }^{72}$ Nor was osteopetrosis reported for $\mathrm{Nik}^{-/-}$mice. ${ }^{71}$ In addition, we found that a mutation that prevents IKK $\alpha$ activation has no effect on bone development or inflammation induced bone loss in vivo. ${ }^{73}$

Nonetheless, a pivotal role for transcription factor NF- $\kappa \mathrm{B}$ in regulation of inflammation has been well recognised. ${ }^{74}$ As mentioned above, the relevance of NF- $\kappa B$ pathway to osteoclastogenesis is underscored by the osteopetrotic phe-

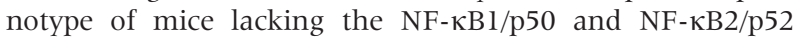
subunits. ${ }^{22}{ }^{23}$ Interestingly, a deficiency in a single subunit has no effect on osteoclast formation or maturation. The question, however, is which catalytic subunit is required for $\mathrm{NF}-\kappa \mathrm{B}$ activation during osteoclastogenesis and inflammation induced bone loss.

$\mathrm{NF}-\mathrm{\kappa B}$ controls the expression of the proinflammatory cytokines IL- $1 \beta$ and TNF $\alpha$, which are important mediators of inflammation in RA. In turn, both TNF $\alpha$ and IL- $1 \beta$ are potent inducers of NF- $\kappa B$ activation, suggesting an interdependence of persistent NF- $\kappa B$ activation and sustained IL- $1 \beta$ and TNF $\alpha$ production. Indeed, expression of a non-phosphorylable

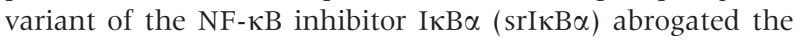
induction of IL- $1 \beta$ and TNF $\alpha$ in human macrophages and primary fibroblast-like synoviocytes (FLS). ${ }^{76} 77$ More importantly, a small synthetic peptide that disrupts the interaction between IKK $\beta$ and the IKK $\gamma$ regulatory subunit and therefore prevents IKK activation was found to inhibit inflammationinduced bone loss in a mouse model of arthritis. ${ }^{78}$

A recent study from our laboratory established that IKK $\beta$, but not IKK $\alpha$, is essential for inflammation induced bone loss and is required for osteoclastogenesis in vivo. ${ }^{73}$ Bone marrow cells deficient in IKK $\beta$ do not form osteoclasts in vitro when stimulated with RANKL. Furthermore, mice lacking IKK $\beta$ in haematopoietic cells and hepatocytes, Ikk $\beta^{4}$ mice, are osteopetrotic, due to the lack of osteoclasts, indicating that IKK $\alpha$ function is dispensable in vivo in the RANK signalling pathway (fig l).

However, the main function of IKK $\beta$ in osteoclastogenesis is to prevent TNF $\alpha$ induced apoptosis of osteoclast precursors (see fig 1). Indeed, bone marrow cells deficient in IKK $\beta$ are extremely sensitive to TNF $\alpha$ induced apoptosis and die in response to elevated TNF $\alpha$. Loss of TNF-Rl prevents apoptosis in IKK $\beta$ deficient BM cells and restores the presence of osteoclasts in mice that lack both IKK $\beta$ and TNF-Rl in the relevant cells, Ikk $\beta^{4} / \operatorname{Tnfr} I^{-/-}$mice. Nonetheless, the prevention of TNF $\alpha$ induced death reveals that IKK $\beta$ is also required for maturation of functional osteoclasts, because Ikk $\beta^{4} / \operatorname{TnfrI} I^{-/-}$osteoclasts are defective in bone resorption. Inflammation induced bone loss is prevented in mice lacking IKK $\beta$, because IKK $\beta$ deficient osteoclasts and preosteoclasts are killed by TNF $\alpha$. Once the effect of $\mathrm{TNF} \alpha$ is eliminated by ablation of its receptor, inflammation induced bone loss is restored in Ikk $\beta^{4} / \operatorname{Tnfrl} 1^{-1-}$ mice. ${ }^{73}$ Thus, despite the inability of IKK $\beta$ and TNF-RI deficient osteoclasts to undergo functional maturation (that is, become active in bone resorption) under non-inflamed condition, in the presence of a strong inflammatory stimulus, such as the one generated by LPS-injection into the joint, these cells undergo maturation after all. ${ }^{73}$ The inflammatory cytokines that induce the functional maturation of $I k k \beta^{\Delta}$, $\mathrm{Tnfrl}^{-1-}$ osteoclast precursors remain to be identified.

\section{THERAPEUTIC INTERVENTIONS}

Knowledge of the pathogenic mechanisms of inflammatory arthritis has led to the design of targeted therapies that are effective in suppression of inflammation and prevention of joint destruction. The current anti-inflammatory and antirheumatic drugs used to treat RA include glucocorticoids, aspirin, sodium salicylate, sulfasalazine, and gold compounds, all of which have been shown to block NF- $\kappa B$ activity. ${ }^{79}$ The list of therapeutic agents that inhibit NF- $\kappa B$ also includes numerous natural and synthetic antioxidants, immunosuppressants, and natural plant compounds, suggesting that the ability to suppress NF- $\kappa \mathrm{B}$ activation at least partially accounts for their therapeutic effects. ${ }^{79}$ These compounds are neither potent nor selective for this pathway, however, and may have a range of undesirable side effects as a result of their non-specific nature. Consequently, response to treatment in RA patients is not always complete, and in a subset of patients, focal bone erosion progresses despite therapy. More clear answers were obtained using animals with genetically inactivated NF- $\kappa$ B signalling. Ablation of the $n f-\kappa b l$ and $r e l$ genes rendered the affected animals refractory to development of collagen induced arthritis (CIA) ${ }^{80}$ Transgenic mice expressing a super-repressor form of IкB $\alpha$ $(\operatorname{srI\kappa B} \alpha)$ in the $\mathrm{T}$ lineage were similarly refractory to CIA. ${ }^{81}$ These genetic studies are in a good agreement with the experiments that used highly specific inhibitors of NF- $\mathrm{KB}$. However, the safety of long term use of specific NF- $\kappa B$ inhibitors remains to be elucidated. Genetic studies revealed

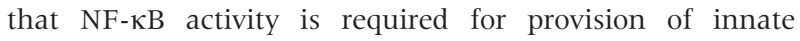
immunity and prevention of opportunistic infections. ${ }^{82}$ Highly specific inhibitors, local delivery, and short term treatments should alleviate the possible side effects associated with systemic inhibition and minimise the risk of general immunosuppression.

In this context, the results from our knockout experiments $^{73}$ and those obtained by the use of IKK peptide inhibitor $^{78}$ are exciting. They indicate that specific and selective inhibition of the IKK $\beta$ subunit and the classical $\mathrm{NF}-\kappa \mathrm{B}$ activation pathway represent an effective approach to the treatment of inflammatory diseases causing bone resorption. Furthermore, during inflammation, proinflammatory cytokines such as TNF $\alpha$ and IL-1 $\beta$ are induced and strongly potentiate RANKL induced osteoclastogenesis, although such factors cannot induce osteoclast differentiation on their own. ${ }^{73}{ }^{34} \mathrm{TNF} \alpha$ signalling through TNF-Rl has the potential to induce apoptosis through caspase 8 , a process that is prevented by IKK $\beta$ dependent NF- $\kappa \mathrm{B}$ activation. ${ }^{39}$ Once IKK $\beta$ is inhibited, TNF $\alpha$ induced apoptosis can 
eliminate osteoclast progenitors deficient in $\operatorname{Ikk} \beta$, thereby preventing inflammation induced bone destruction. Thus, IKK $\beta$ inhibition presents a logical strategy for the therapy of numerous bone resorbing inflammatory disorders in which $\mathrm{TNF} \alpha$ is elevated, such as RA. However, the efficacy of such an approach would be severely compromised if TNF $\alpha$ signalling, responsible for the elimination of IKK $\beta$ inhibited osteoclast progenitors, is blocked by anti-TNF $\alpha$ drugs, such as infliximab and etanercept. Thus, when IKK $\beta$ inhibitors will become available it is unlikely that they will be useful in conjunction with the currently available anti-TNF $\alpha$ therapeutic agents.

\section{Authors' affiliations}

M G Ruocco, M Karin, Laboratory of Gene Regulation and Signal Transduction, School of Medicine, University of California at San Diego, La Jolla, CA, USA

Competing interests: none declared

Correspondence to: M Karin; karinoffice@ucsd.edu

\section{REFERENCES}

1 Lawrence T, Willoughby DA, Gilroy DW. Anti-inflammatory lipid mediators and insights into the resolution of inflammation. Nat Rev Immunol 2002;2:787-95

2 Roodman GD. Cell biology of the osteoclast. Exp Hematol 1999;27:1229-41.

3 Kong YY, Feige U, Sarosi I, Bolon B, Tafuri A, Morony S, et al. Activated T cells regulate bone loss and joint destruction in adjuvant arthritis through osteoprotegerin ligand. Nature 1999;402:304-9.

4 Gravallese EM. Bone destruction in arthritis. Ann Rheum Dis 2002;61(suppl 2):ii84-ii86.

5 Suzuki Y, Nishikaku F, Nakatuka M, Koga Y. Osteoclast-like cells in murine collagen induced arthritis. J Rheumatol 1998;25:1154-60.

6 Leisen JC, Duncan H, Riddle JM, Pitchford WC. The erosive front: a topographic study of the junction between the pannus and the subchondral plate in the macerated rheumatoid metacarpal head. J Rheumatol 1988;15:17-22.

7 Karsenty G, Wagner EF. Reaching a genetic and molecular understanding of skeletal development. Dev Cell 2002;2:389-406.

8 Reddi AH. Bone morphogenesis and modeling: soluble signals sculpt osteosomes in the solid state. Cell 1997;89:159-61

9 Mostov K, Werb Z. Journey across the osteoclast. Science 1997; 276:219-20.

$10 \mathrm{Ji} \mathrm{H}$, Pettit A, Ohmura K, Ortiz-Lopez A, Duchatelle V, Degott C, et al. Critical roles for interleukin 1 and tumor necrosis factor alpha in antibody-induced arthritis. J Exp Med 2002;196:77-85

11 Shealy DJ, Wooley PH, Emmell E, Volk A, Rosenberg A, Treacy G, et al. AntiTNF-alpha antibody allows healing of joint damage in polyarthritic transgenic mice. Arthritis Res 2002;4:R7.

12 Redlich K, Hayer S, Ricci R, David JP, Tohidast-Akrad M, Kollias G, et al Osteoclasts are essential for TNF-alpha-mediated joint destruction. J Clin Invest 2002;110:1419-27.

13 Zwerina J, Hayer S, Tohidast-Akrad M, Bergmeister H, Redlich K, Feige U, et al. Single and combined inhibition of tumor necrosis factor, interleukin-1, and RANKL pathways in tumor necrosis factor-induced arthritis: effects on synovial inflammation, bone erosion, and cartilage destruction. Arthritis Rheum 2004;50:277-90

14 Pettit AR, Ji H, von Stechow D, Muller R, Goldring SR, Choi Y, et al. TRANCE/ RANKL knockout mice are protected from bone erosion in a serum transfer model of arthritis. Am J Pathol 2001;159:1689-99.

15 Nakashima T, Wada T, Penninger JM. RANKL and RANK as novel therapeutic targets for arthritis. Curr Opin Rheumatol 2003;15:280-7.

16 Romas E, Sims NA, Hards DK, Lindsay M, Quinn JW, Ryan PF, et al. Osteoprotegerin reduces osteoclast numbers and prevents bone erosion in collagen-induced arthritis. Am J Pathol 2002;161:1419-27.

17 Boyle WJ, Simonet WS, Lacey DL. Osteoclast differentiation and activation. Nature 2003:423:337-42.

18 Lacey DL, Timms E, Tan HL, Kelley MJ, Dunstan CR, Burgess T, et al. Osteoprotegerin ligand is a cytokine that regulates osteoclast differentiation and activation. Cell 1998;93:165-76.

19 Kong YY, Yoshida H, Sarosi I, Tan HL, Timms E, Capparelli C, et al. OPGL is a key regulator of osteoclastogenesis, lymphocyte development and lymph-node organogenesis. Nature 1999;397:315-23.

20 Dougall WC, Glaccum M, Charrier K, Rohrbach K, Brasel K, De Smedt T, et al. RANK is essential for osteoclast and lymph node development. Genes Dev $1999 ; 13: 2412-24$.

21 Simonet WS, Lacey DL, Dunstan CR, Kelley M, Chang MS, Luthy R, et al. Osteoprotegerin: a novel secreted protein involved in the regulation of bone density. Cell 1997;89:309-19.

22 lotsova V, Caamano J, Loy J, Yang Y, Lewin A, Bravo R. Osteopetrosis in mice lacking NF-kappaB1 and NF-kappaB2. Nat Med 1997;3:1285-9.
23 Franzoso G, Carlson L, Xing L, Poljak L, Shores EW, Brown KD, et al. Requirement for NF-kappaB in osteoclast and B-cell development. Genes Dev 1997; 11:3482-96.

24 Lee SE, Woo KM, Kim SY, Kim HM, Kwack K, Lee ZH, et al. The phosphatidylinositol 3-kinase, p38, and extracellular signal-regulated kinase pathways are involved in osteoclast differentiation. Bone 2002;30:71-7.

25 Wong BR, Besser D, Kim N, Arron JR, Vologodskaia M, Hanafusa H, et al. TRANCE, a TNF family member, activates Akt/PKB through a signaling complex involving TRAF6 and c-Src. Mol Cell 1999;4:1041-9.

26 Soriano P, Montgomery C, Geske R, Bradley A. Targeted disruption of the csrc proto-oncogene leads to osteopetrosis in mice. Cell 1991;64:693-702.

27 Chellaiah M, Fitzgerald C, Alvarez U, Hruska K. c-Src is required for stimulation of gelsolin-associated phosphatidylinositol 3-kinase. J Biol Chem 1998;273:11908-16.

28 Duong LT, Lakkakorpi PT, Nakamura I, Machwate M, Nagy RM, Rodan GA. PYK2 in osteoclasts is an adhesion kinase, localized in the sealing zone, activated by ligation of alpha(v)beta3 integrin, and phosphorylated by src kinase. J Clin Invest 1998;102:881-92.

29 Tanaka S, Amling M, Neff L, Peyman A, Uhlmann E, Levy JB, et al. c-Cbl is downstream of c-Src in a signalling pathway necessary for bone resorption. Nature 1996;383:528-31.

30 Bolon B, Campagnuolo G, Feige U. Duration of bone protection by a single osteoprotegerin injection in rats with adjuvant-induced arthritis. Cell Mol Life Sci 2002;59:1569-76.

31 Campagnuolo G, Bolon B, Feige U. Kinetics of bone protection by recombinant osteoprotegerin therapy in Lewis rats with adjuvant arthritis. Arthritis Rheum 2002;46:1926-36.

32 Schett G, Redlich K, Hayer S, Zwerina J, Bolon B, Dunstan C, et al. Osteoprotegerin protects against generalized bone loss in tumor necrosis factor-transgenic mice. Arthritis Rheum 2003;48:2042-51.

33 Kobayashi K, Takahashi N, Jimi E, Udagawa N, Takami M, Kotake S, et al. Tumor necrosis factor alpha stimulates osteoclast differentiation by a mechanism independent of the ODF/RANKL-RANK interaction. J Exp Med 2000;191:275-86

34 Lam J, Takeshita S, Barker JE, Kanagawa O, Ross FP, Teitelbaum SL. TNFalpha induces osteoclastogenesis by direct stimulation of macrophages exposed to permissive levels of RANK ligand. J Clin Invest 2000;106:1481-8.

35 Zhang YH, Heulsmann A, Tondravi MM, Mukherjee A, Abu-Amer Y. Tumor necrosis factor-alpha (TNF) stimulates RANKL-induced osteoclastogenesis via coupling of TNF type 1 receptor and RANK signaling pathways. J Biol Chem 2001;276:563-8.

36 Abu-Amer Y, Erdmann J, Alexopoulou L, Kollias G, Ross FP, Teitelbaum SL. Tumor necrosis factor receptors types 1 and 2 differentially regulate osteoclastogenesis. J Biol Chem 2000;275:27307-10.

37 Zou W, Hakim I, Tschoep K, Endres S, Bar-Shavit Z. Tumor necrosis factoralpha mediates RANK ligand stimulation of osteoclast differentiation by an autocrine mechanism. J Cell Biochem 2001;83:70-83.

38 Sato T, Selleri C, Anderson S, Young NS, Maciejewski JP. Expression and modulation of cellular receptors for interferon-gamma, tumour necrosis factor, and Fas on human bone marrow CD34+ cells. Br J Haematol 1997;97:356-65.

39 Karin M, Lin A. NF-kappaB at the crossroads of life and death. Nat Immunol 2002;3:221-7.

40 Hsu H, Shu HB, Pan MG, Goeddel DV. TRADD-TRAF2 and TRADD-FADD interactions define two distinct TNF receptor 1 signal transduction pathways. Cell 1996;84:299-308.

41 Liu ZG, Hsu H, Goeddel DV, Karin M. Dissection of TNF receptor 1 effector functions: JNK activation is not linked to apoptosis while NF-kappaB activation prevents cell death. Cell 1996;87:565-76.

42 Maeda S, Chang L, Li ZW, Luo JL, Leffert H, Karin M. IKKbeta is required for prevention of apoptosis mediated by cell-bound but not by circulating TNFalpha. Immunity 2003;19:725-37.

43 MacNaul KL, Hutchinson NI, Parsons JN, Bayne EK, Tocci MJ. Analysis of ILand TNF-alpha gene expression in human rheumatoid synoviocytes and normal monocytes by in situ hybridization. J Immunol 1990;145:4154-66.

44 Danning CL, Illei GG, Hitchon C, Greer MR, Boumpas DT, Mclnnes IB. Macrophage-derived cytokine and nuclear factor kappaB p65 expression in synovial membrane and skin of patients with psoriatic arthritis. Arthritis Rheum 2000:43:1244-56

45 Elliołt MJ, Maini RN, Feldmann M, Kalden JR, Antoni C, Smolen JS, et al. Randomised double-blind comparison of chimeric monoclonal antibody to tumour necrosis factor alpha (cA2) versus placebo in rheumatoid arthritis. Lancet 1994:344:1 105-10.

46 Maini RN, Breedveld FC, Kalden JR, Smolen JS, Davis D, Macfarlane JD, et al. Therapeutic efficacy of multiple intravenous infusions of anti-fumor necrosis factor alpha monoclonal antibody combined with low-dose weekly methotrexate in rheumatoid arthritis. Arthritis Rheum 1998:41:1552-63.

47 Maini R, St Clair EW, Breedveld F, Furst D, Kalden J, Weisman M, et al. Infliximab (chimeric anti-tumour necrosis factor alpha monoclonal antibody) versus placebo in rheumatoid arthritis patients receiving concomitant methotrexate: a randomised phase III trial. ATTRACT Study Group. Lancet 1999:354:1932-9.

48 Lipsky PE, van der Heijde DM, St Clair EW, Furst DE, Breedveld FC, Kalden JR, et al. Infliximab and methotrexate in the treatment of rheumatoid arthritis. Anti-Tumor Necrosis Factor Trial in Rheumatoid Arthritis with Concomitant Therapy Study Group. N Engl J Med 2000;343:1594-602.

49 Breedveld FC, Emery P, Keystone E, Patel K, Furst DE, Kalden JR, et al. Infliximab in active early rheumatoid arthritis. Ann Rheum Dis 2004:63: 149-55. 
50 Campbell IK, O'Donnell K, Lawlor KE, Wicks IP. Severe inflammatory arthritis and lymphadenopathy in the absence of TNF. J Clin Invest 2001; 107:1519-27.

51 Moreland LW, Baumgartner SW, Schiff MH, Tindall EA, Fleischmann RM Weaver AL, et al. Treatment of rheumatoid arthritis with a recombinant human tumor necrosis factor receptor (p75)-Fc fusion protein. N Engl J Med 1997;337:141-7.

52 Moreland LW, Schiff MH, Baumgartner SW, Tindall EA, Fleischmann RM, Bulpitt $\mathrm{KJ}$, et al. Etanercept therapy in rheumatoid arthritis. A randomized, controlled trial. Ann Intern Med 1999;130:478-86.

53 Bathon JM, Martin RW, Fleischmann RM, Tesser JR, Schiff MH, Keystone EC, et al. A comparison of etanercept and methotrexate in patients with early rheumatoid arthritis. N Engl J Med 2000;343:1586-93.

54 Genovese MC, Bathon JM, Martin RW, Fleischmann RM, Tesser JR, Schiff MH, et al. Etanercept versus methotrexate in patients with early rheumatoid arthritis: two-year radiographic and clinical outcomes. Arthritis Rheum 2002;46: 1443-50.

55 Weinblatt ME, Kremer JM, Bankhurst AD, Bulpitt KJ, Fleischmann RM, Fox RI, et al. A trial of etanercept, a recombinant tumor necrosis factor receptor: $\mathrm{Fc}$ fusion protein, in patients with rheumatoid arthritis receiving methotrexate. N Engl J Med 1999;340:253-9.

56 Kremer JM, Weinblatt ME, Bankhurst AD, Bulpitt KJ, Fleischmann RM, Jackson CG, et al. Etanercept added to background methotrexate therapy in patients with rheumatoid arthritis: continued observations. Arthritis Rheum 2003;48:1493-9.

57 den Broeder AA, Joosten LA, Saxne T, Heinegard D, Fenner H, Miltenburg $A M$, et al. Long term anti-tumour necrosis factor alpha monotherapy in rheumatoid arthritis: effect on radiological course and prognostic value of markers of cartilage turnover and endothelial activation. Ann Rheum Dis 2002;61:311-18.

58 den Broeder A, van de Putte L, Rau R, Schattenkirchner M, Van Riel P, Sander $\mathrm{O}$, et al. A single dose, placebo controlled study of the fully human anti-tumor necrosis factor-alpha antibody adalimumab (D2E7) in patients with rheumatoid arthritis. J Rheumatol 2002;29:2288-98.

59 Weinblatt ME, Keystone EC, Furst DE, Moreland LW, Weisman MH, Birbara CA, et al. Adalimumab, a fully human anti-tumor necrosis factor alpha monoclonal antibody, for the treatment of rheumatoid arthritis in patients taking concomitant methotrexate: the ARMADA trial. Arthritis Rheum 2003;48:35-45.

60 Ghosh S, May MJ, Kopp EB. NF-kappa B and Rel proteins: evolutionarily conserved mediators of immune responses. Annu Rev Immunol 1998; 16:225-60.

61 Karin M, Ben-Neriah Y. Phosphorylation meets ubiquitination: the control of NF-[kappa]B activity. Annu Rev Immunol 2000;18:621-63.

62 Rothwarf DM, Karin M. The NF-kappa B activation pathway: a paradigm in information transfer from membrane to nucleus. Sci STKE 1999; 1999:RE

63 Mercurio F, Zhu H, Murray BW, Shevchenko A, Bennett BL, Li J, et al. IKK-1 and IKK-2: cytokine-activated IkappaB kinases essential for NF-kappaB activation. Science 1997;278:860-6.

64 Zandi E, Rothwarf DM, Delhase M, Hayakawa M, Karin M. The IkappaB kinase complex (IKK) contains two kinase subunits, IKKalpha and IKKbeta, necessary for lkappaB phosphorylation and NF-kappaB activation. Cell $1997 ; 91: 243-52$
65 Hu Y, Baud V, Delhase M, Zhang P, Deerinck T, Ellisman M, et al. Abnormal morphogenesis but intact IKK activation in mice lacking the IKKalpha subunit of IkappaB kinase. Science 1999;284:316-20.

66 Li ZW, Chu W, Hu Y, Delhase M, Deerinck T, Ellisman M, et al. The IKKbeta subunit of IkappaB kinase (IKK) is essential for nuclear factor kappaB activation and prevention of apoptosis. J Exp Med 1999;189:1839-45.

67 Li Q, Van Antwerp D, Mercurio F, Lee KF, Verma IM. Severe liver degeneration in mice lacking the lkappaB kinase 2 gene. Science 1999:284:321-5.

68 Senftleben U, Li ZW, Baud V, Karin M. IKKbeta is essential for protecting T cells from TNFalpha-induced apoptosis. Immunity 2001;14:217-30.

69 Hu Y, Baud V, Oga T, Kim KI, Yoshida K, Karin M. IKKalpha controls formation of the epidermis independently of NF-kappaB. Nature 2001;410:710-14.

70 Senftleben U, Cao Y, Xiao G, Greten FR, Krahn G, Bonizzi G, et al. Activation by IKKalpha of a second, evolutionary conserved, NF-kappa B signaling pathway. Science 2001;293:1495-9.

71 Novack DV, Yin L, Hagen-Stapleton A, Schreiber RD, Goeddel DV, Ross FP, et al. The IkappaB function of NF-kappaB2 p100 controls stimulated osteoclastogenesis. J Exp Med 2003;198:771-81.

72 Shinkura R, Kitada K, Matsuda F, Tashiro K, Ikuta K, Suzuki M, et al. Alymphoplasia is caused by a point mutation in the mouse gene encoding Nfkappa b-inducing kinase. Nat Genet 1999;22:74-7.

73 Ruocco MG, Maeda S, Park JM, Lawrence T, Hsu LC, Cao Y, et al. I\{kappa\}B kinase (IKK)\{beta\}, but not IKK\{alpha\}, is a critical mediator of osteoclast survival and is required for inflammation-induced bone loss. J Exp Med 2005;201:1677-87.

74 Barnes PJ, Karin M. Nuclear factor-kappaB: a pivotal transcription factor in chronic inflammatory diseases. N Engl J Med 1997;336:1066-71.

75 Tak PP, Firestein GS. NF-kappaB: a key role in inflammatory diseases. J Clin Invest 2001;107:7-11.

76 Miagkov AV, Kovalenko DV, Brown CE, Didsbury JR, Cogswell JP Stimpson SA, et al. NF-kappaB activation provides the potential link between inflammation and hyperplasia in the arthritic joint. Proc Natl Acad Sci U S A 1998;95:13859-64.

77 Foxwell B, Browne K, Bondeson J, Clarke C, de Martin R, Brennan F, et al. Efficient adenoviral infection with lkappaB alpha reveals that macrophage tumor necrosis factor alpha production in rheumatoid arthritis is NF-kappaB dependent. Proc Natl Acad Sci U S A 1998;95:8211-15.

78 Jimi E, Aoki K, Saito H, D'Acquisto F, May MJ, Nakamura I, et al. Selective inhibition of NF-kappa B blocks osteoclastogenesis and prevents inflammatory bone destruction in vivo. Nat Med 2004;10:617-24.

79 Epinat JC, Gilmore TD. Diverse agents act at multiple levels to inhibit the Rel/ NF-kappaB signal transduction pathway. Oncogene 1999;18:6896-909.

80 Campbell IK, Gerondakis S, O'Donnell K, Wicks IP. Distinct roles for the NFkappaB 1 (p50) and c-Rel transcription factors in inflammatory arthritis. J Clin Invest 2000;105: 1799-806.

81 Seetharaman R, Mora AL, Nabozny G, Boothby M, Chen J. Essential role of T cell NF-kappa B activation in collagen-induced arthritis. J Immunol 1999:163:1577-83.

82 Bonizzi G, Karin M. The two NF-kappaB activation pathways and their role in innate and adaptive immunity. Trends Immunol 2004;25:280-8. 